\title{
Kemampuan Motorik Halus Anak melalui Kegiatan Menganyam Menggunakan Eceng Gondok dengan Teknik Kepang
}

\author{
Dian Ayu Hidayani*, I Made Seken, Nur Anisa \\ Universitas Negeri Malang, Jl. Semarang No. 5 Malang, Jawa Timur, Indonesia \\ *Penulis korespondensi, Surel: dianayuhidayani@gmail.com
}

Paper received: 2-2-2021; revised: 20-2-2021; accepted: 27-2-2021

\begin{abstract}
This study aims to improve the fine motor skills of children in group B kindegarten Mekarsari Lamongan. Activities that will be carried out to improve the fine motor skills of children in group B of Mekarsari kindergarten Lamongan are by weaving using water hyacinth with braid techniques. The type of research used is classroom action research (PTK). The type of data used in the research is quantitative and qualitative data. Research weaving using water hyacinth with this braid technique results that are started from pre-action activities with a score of 41.8 with 12 percent percentage while the first cycle gets a score of 49.6 with a percentage of 18 percent and the second cycle scores 86.16 with a percentage of 84 percent. Research on improving children's fine motor skills through weaving using water hyacinth is increasing well and the teacher can use the surrounding plants to weave the child's fine motor skills.
\end{abstract}

Keywords: fine motorbike; weaving hyacinth; braid technique

\begin{abstract}
Abstrak
Penelitian ini bertujuan untuk meningkatkan kemampuan motorik halus anak kelompok B TK Mekarsari Lamongan. Kegiatan yang akan dilaksanakan untuk meningkatkan kemampuan motorik halus anak kelompok B TK Mekarsari Lamongan yaitu dengan kegiatan menganyam menggunakan eceng gondok dengan teknik kepang. Jenis penelitian yang digunakan adalah penelitian tindakan kelas (PTK). Jenis data yang digunakan dalam penelitian yaitu data kuantitatif dan kualitatif. Penelitian menganyam menggunakan eceng gondok dengan teknik kepang ini hasil yang dimulai dari kegiatan pratindakan dengan skor 41,8 dengan 12 persentase sedangkan siklus I memperoleh skor 49,6 dengan persentase 18 persen dan siklus II memperoleh skor 86,16 dengan persentase 84 persen. Penelitian peningkatan motorik halus anak melalui kegiatan menganyam menggunakan eceng gondok ini meningkat dengan baik dan guru bisa memanfaatkan tanaman yang ada disekitar untuk menganyam melatih kemampuan motorik halus anak.
\end{abstract}

Kata kunci: motorik halus; menganyam eceng gondok; teknik kepang

\section{Pendahuluan}

Pada masa anak usia dini penyerapan informasi yang akan berlangsung sangat cepat dan tepat dalam merespon informasi, sehingga pada masa ini anak akan banyak melakukan peniruan terhadap bahasa, emosional, dan perilaku yang melibatkan gerakan-gerakan pada tubuh anak. Masa ini dikenal dengan masa the golden age (Aisyah, 2013). Perkembangan anak usia dini pada perkembangan fisik motorik memegang peran yang sama pentingnya dengan perkembangan kognisi, perilaku sosial, dan kepribadian. Pada masa tersebut anak bergerak secara aktif sehingga mampu menguasai tubuhnya. Perkembangan fisik motorik merupakan tingkah laku motorik yang memperlihatkan interaksi dari kematangan individu yang terjadi secara terus menerus sepanjang kehidupan manusia. Fisik motorik di bagi menjadi 2 motorik kasar dan motorik halus. Motorik kasar yaitu koordinasi kelompok otot-otot anak yang 
tertentu dapat membuat anak melompat, memanjat, berlari dan menaiki sepeda, sedangkan motorik halus yaitu meningkatnya pengordinasian gerak tubuh yang melibatkan otot syaraf yang jauh lebih kecil atau detail. Kelompok otot dan syaraf inilah yang nantinya mampu mengembangkan gerak motorik halus, seperti meremas kertas, menyobek, menggambar, dan menulis ( Suyadi, 2010). Sejalan dengan Sumantri (2005) perkembangan motorik halus merupakan pengorganisasian penggunaan sekolompok otot-otot kecil seperti jari-jemari dan tangan yang sering membutuhkan kecermatan dan koordinasi mata dengan tangan.

Berhubungan dengan kemampuan anak untuk melakukan gerakan pada bagian-bagian tubuh tertentu saja dapat dilakukan oleh otot-otot kecil tetapi memerlukan koordinasi yang cermat. Gerakan ini hanya membutuhkan koordinasi mata dan tangan yang cermat, sehingga tidak perlu mengeluarkan tenaga yang kuat untuk menggunakannya. Semakin baik gerakan motorik halus anak, maka anak akan mampu berkreasi dengan maksimal. Aspek perkembangan fisik motorik halus di TK Mekarsari kurang berkembang secara optimal. Kegiatan di TK Mekarsari terkait perkembangan fisik motorik halus kurang bervariasi. Kegiatan perkembangan motorik halusnya hanya meliputi menulis, menggambar dan mencocok.

Berdasarkan hasil observasi pada tanggal 08 November 2018 anak saat melakukan kegiatan berkaitan dengan motorik halus dapat disimpulkan bahwa keterampilan motorik halus pada anak kelompok B masih memerlukan banyak stimulasi. Hal ini terbukti dari sebagian besar anak kelompok B mengalami kesulitan pada saat diberikan tugas mewarnai. Ada 10 anak yang dalam kegiatan mewarnai masih keluar garis yang disebabkan oleh aspek kelenturan otot tangan yang kurang maksimal, sehingga anak kurang rapi dalam mewarnai dan anak mudah bosan dalam kegiatan tersebut. Pada kegiatan menganyam menggunakan kertas, dari 25 anak terdapat 15 anak yang kurang bisa mengkoordinasikan antara mata dan tangan sehingga hasil menganyamnya masih belum selesai dan belum bisa maksimal, selain itu pada kegiatan mencocok bentuk pola persegi, ada 11 anak yang belum bisa berkonsentrasi dalam kegiatan tersebut sehingga hasil yang diperoleh kurang rapi bahkan robek. Kegiatan menganyam pada kelompok B masih jarang dilakukan, hampir setiap hari kegiatan pembelajaran di kelompok B menggunakan LKA, sehingga dalam pembelajaran tersebut membuat anak menjadi jenuh dan kurang tertarik. Kurangnya variasi kegiatan, maka peneliti ingin meningkatkan perkembangan fisik motorik halus melalui kegiatan menganyam. Melalui kegiatan menganyam ini diharapkan perkembangan fisik motorik halus anak meningkat

Menganyam adalah salah satu bagian dari keterampilan yang bertujuan untuk menghasilkan sebuah hasil karya berupa benda atau barang pakai yang dilakukan dengan cara saling menumpang tindihkan lungsi (bagian yang disusun vertikal) dan pakan (bagian yang disusun horizontal) secara bergantian hingga menyatu (Nasir, 2013). Peneliti menggunakan eceng gondok sebagai bahan menganyam agar memudahkan anak dalam belajar keterampilan menganyam. Alasan pertama pemakaian eceng gondok digunakan sebagai kegiatan menganyam karena tekstur eceng gondok lentur, lebar dan panjang sehingga mempermudah anak dalam melakukan kegiatan menganyam. Terdapat beberapa macam jenis bahan anyaman yang dapat digunakan dalam kegiatan praktik keterampilan dasar menganyam di TK. Menurut Sumanto (2005), berikut salah satunya adalah eceng gondok. Alasan kedua yaitu banyak dijumpai eceg gondok disekitar desa oleh karena itu peneliti ingin memanfaatkan tanaman yang ada disekitarnya. Alasan ketiga yaitu banyak dijumpai pengrajin anyaman yang menggunakan eceng gondok sebagai bahan menganyam. Kegiatan menganyam pada anak 
kelompok B menggunakan teknik menganyam kepang. Alasan penggunaan teknik kepang pada kegiatan menganyam di kelompok B karena teknik menganyam kepang memiliki tingkat kerumitan yang lebih tinggi dibandingakan teknik menganyam lilit, sehingga teknik anyaman kepang cocok di terapkan untuk anak usia 5-6 tahun.

Penelitian sebelumnya yang dilakukan oleh Rysza (2016) pada kelompok B di TK Dharma Wanita Minggisari Kecamatan Kanigoro Kabupaten Blitar dengan judul "Peningkatan Kemampuan Fisik Motorik Halus Melalui Kegiatan Menganyam Sederhana Kelompok B TK Dharma Wanita Kabupaten Blitar" dikatakan berhasil. Hal ini dapat dilihat dari peningkatan presentase motorik halus pada siklus 1 mencapai 18,75\% dan pada siklus II mencapai 100\% dari jumlah anak telah mencapai ketuntasan sehinngga tidak perlu dilanjutkan ke siklus III.

\section{Metode}

Penelitian tindakan kelas (PTK) adalah penelitian tindakan yang proses investigasi terkendali untuk memecahkan dan menemukan masalah dalam pembelajaran di kelas, proses pemecahan masalah dilakukan secara bersiklus, bertujuan untuk meningkatkan kualitas pembelajaran dan hasil pembelajaran di kelas tertentu Akbar (2010:28).Pendekatan penelitian yang digunakan dalam peneliti ini adalah pendekatan kuantitatif dan kualitatif. Penelitian tindakan kelas ini menggunakan model Kemmis \& Mc Taggart.

Subjek penelitian anak pada kelompok B TK Mekarsari Lamongan, dengan jumlah anak 25 dalam satu kelas. Terdiri dari perempuan 13 dan 12 laki-laki. Data yang akan digunakan dalam penelitian ini adalah data kuantitatif dan data kualitatif yang berupa data peningkatan kemampuan motorik halus anak selama penelitian berlangsung. Data yang akan dikumpulkan berupa 1) lembar wawancara, 2) observasi, lembar observasi guru dan lembar observasi peningkatan anak, 3) dokumentasi dan catatan lapangan. Sumber data penelitian tindakan kelas ini adalah anak kelompok B TK Mekarsari Lamongan.

Analisis data yang akan digunakan dalam penelitian merupakan deskriptif kuantitatif dan deskriptif kualitatif. Data yang akan dianalisis secara kualitatif meruapakan cacatatan lapangan, wawancara, dan data berupa dokumentasi foto kegiatan pembelajaran. Data yang dianalisis secara kuantitatif meruapakan data yang berkaiatan dengan peningkatan kemampuan motorik halus anak melalui menganyam pada skala capaian perkembangan. Data kuantitatif ini dihitung dengan analisis menggunakan statistika sederhana sebagai berikut:

Penilaian ketercapaian kelas merupakan data yang akan digunakan untuk mengetahui tingkat keberhasilan yang sudah dilakukan oleh peneliti. Peneliti menghitung jumlah anak yang akan mendapat skor 70\%, kemudian peneliti membagi dengan jumlah keseluruhan anak. Trianto (2011) berpendapat bahwa anak yang dianggap tuntas dan sudah berhasil apabila skor diperoleh anak sudah mencapai $\geq 70$, sedangkan kelas dianggap mencapai keberhasilan apabila skor yang sudah diperoleh seluruh kelas mencapai $\geq 70 \%$ ketercapaian anak ini di tentukan berdasarkan pada acuan lembar pengamatan peningkatan motorik halus anak melalui menganyam dengan cara menghitung skor yang diperoleh tiap anak. Peneliti menjumlahkan hasil yang di dapat sesuai dengan indikator pencapaian yang telah diperoleh anak dari 3 aspek penilaian, kemudian peniliti membagikan dengan semua skor keseluruhan indikator pencapaian dari 3 aspek tersebut, sehingga yang akan diperoleh anak nilai tunggal yang didapatkan oleh masing-masing anak. 
Tabel 1. Nilai Ketercapaian Anak

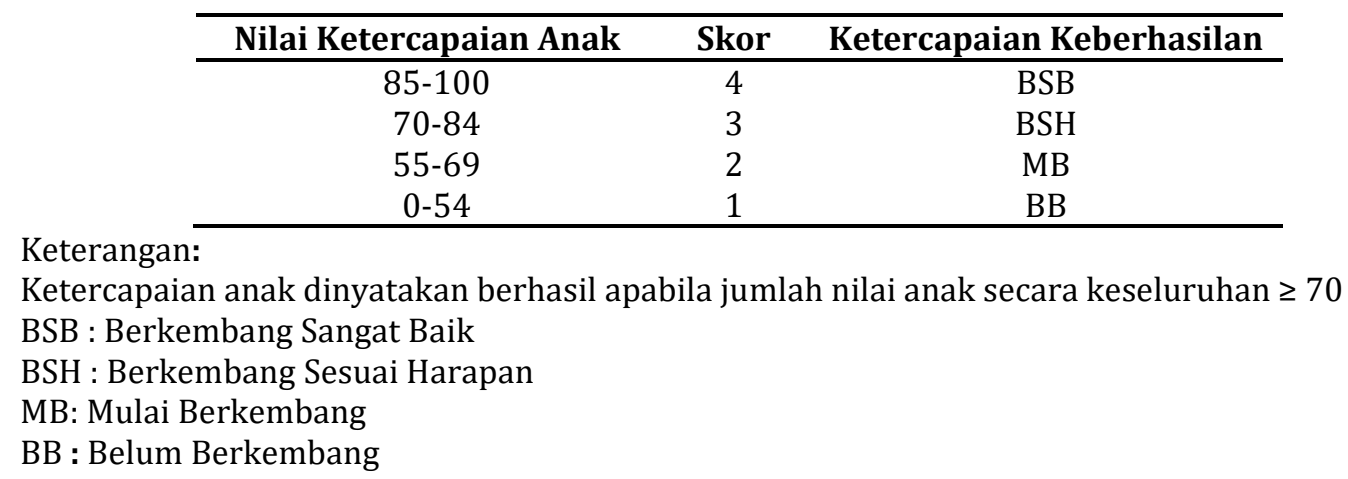

\section{Hasil dan Pembahasan}

Hasil observasi yang diperoleh bahwa kemampuan motorik halus anak belum mencapai hasil maksimal. Dari 25 anak kelompok B hanya 12\% atau 3 anak yang perkembangan fisik motorik halusnya baik, sedangkan 22 anak masih perlu dikembangkan karena ketika pembelajaran berlangsung anak bicara sendiri dengan teman sebelahnya, dan ada yang bermain sendiri dan tidak memperhatikan guru ketika menjelaskan kegiatan pembelajaran.

Hasil penelitian peningkatan motorik halus anak dalam kegiatan menganyam menggunakan eceng gondok dengan teknik kepang pada siklus I pertemuan kedua dapat dilihat langsung pada tabel 4.3. Jumlah yang diperoleh anak dari peningkatan motorik halus anak mempunyai rata-rata 55,6 dengan persentase dari ketuntasan belajar anak $24 \%$ termasuk kriteria belum berkembang. Hal ini disebabkan beberapa anak masih terlalu kaku dan bingung dalam menganyam menggunakan teknik kepang, ditemukan kelemahan yaitu anak masih banyak ramai dan tidak memperhatikan ketika guru sedang menerangkan tentang kegiatan menganyam eceng gondok dengan teknik kepang.

Tabel 2. Hasil Keseluruhan Pada Siklus I

\begin{tabular}{cllc}
\hline No & Penelitian & Skor & Persentase \\
\hline 1 & Pratindakan & 41.8 & 12 \\
2 & Siklus I & 49.6 & 18 \\
\hline
\end{tabular}

Berdasarkan tabel 2 dapat diketahui bahwa pada pratindakan terdapat skor pratindakan 41,8 dengan peresntase 12. Pada siklus I terdapat skor 49,6 dengan persentase 18. Pada kegiatan pratindakan ke siklus I terdapat peningkatan 7,8 skor dengan persentase kenaikan 6, sedangkan pada penerapan siklus I yang sudah dilksanakan mengalami peningkatan dari penelitian pratindakan, hasil peningkatan tersebut dapat dilihat pada gambr diagram 4.6 berikut ini. 


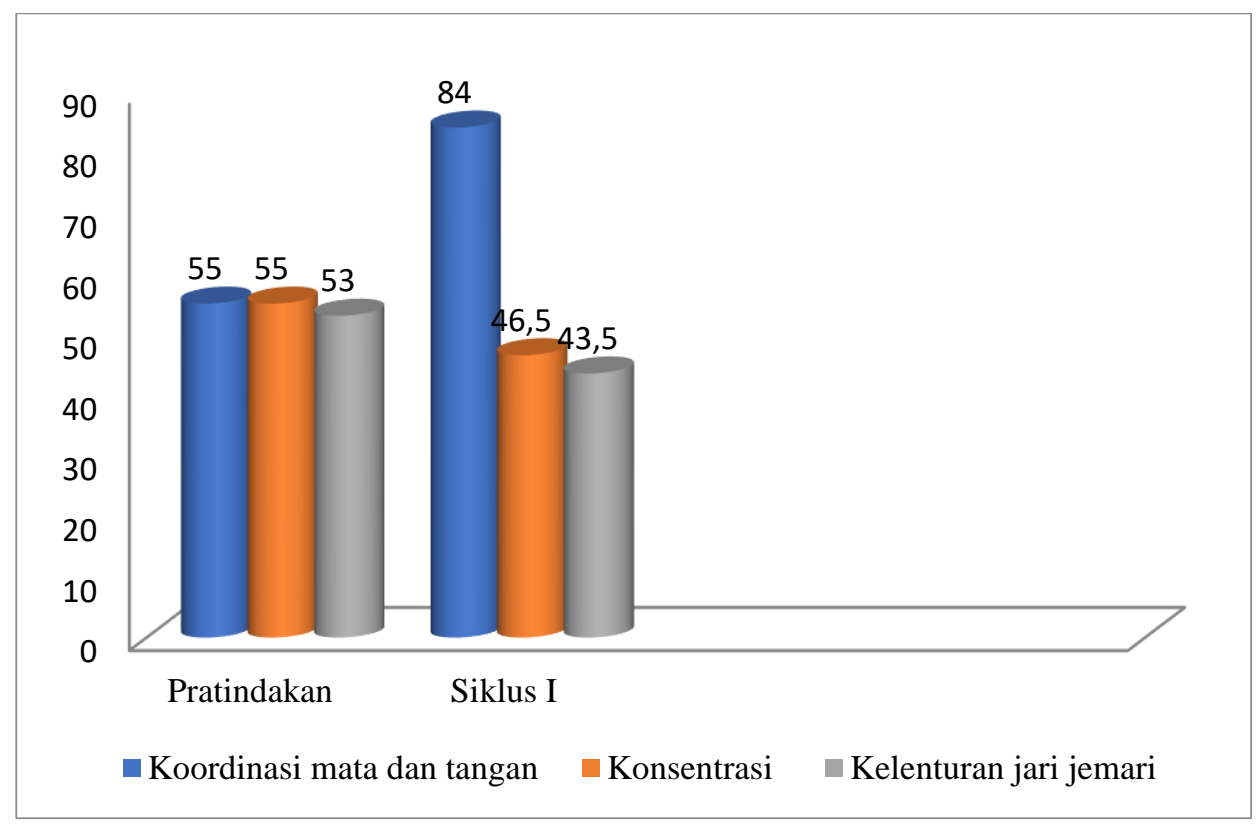

Gambar 1. Diagram hasil peningkatan kemampuan motorik halus anak melalui kegiatan menganyam menggunakan eceng gondok dengan teknik kepang dari pratindakan dan siklus I

Berdasarkan gambar 1 dapat dilihat bahwa paada kegiatakan pratindakan pada koordinasi mata dan tangan dengan nilai 55, pada konsentrasi terdapat nilai 55 dan jai jemari tangan dengan nilai 53. Pada siklus I nilai keseluruhan pada koordinasi mata dan tangan dengan nilai 84, konsentrasi dengan nilai 46,5 dan kelenturan jari jemari tangan dengan nilai 43,5 dengan kategori mulai berkembang oleh karena itu penelitian dilanjut dengan siklus berikutnya.

Hasil penelitian peningkatan motorik halus anak dalam kegiatan menganyam menggunakan eceng gondok dengan teknik kepang pada siklus II peretemuan pertama dapat dilihat pada tabel 4.5. Jumlah yang diperoleh dari peningkatan motorik halus anak sebesar 2058 dan rata-rata 82.32 dengan persentase dari ketuntasan belajar anak 68\% termasuk dengan kriteria belum tercapai ada 17 anak yang sudah berhasil dan 8 anak belum tercapai. Hal ini disebabkan beberapa anak masih terlalu kaku dan bingung dalam menganyam menggunakan teknik kepang, ditemukan kelemahan yaitu anak masih banyak ramai dan tidak memperhatikan ketika guru sedang menerangkan tentang kegiatan menganyam eceng gondok dengan teknik kepang.

Hasil penilaian siklus II persentase kentuntsan anak mencapai $100 \%$ sehingga dapat disimpulkan, bahwa dengan penerapan kegiatan menganyam menggunakan eceng gondok dengan teknik kepang dapat meningkatkan kemampuan motorik halus anak kelompok B TK Mekarsari Lamongan. 
Tabel 3. Hasil Keseluruhan Pada Siklus II

\begin{tabular}{cccc}
\hline No & Penelitian & Skor & Persentase \\
\hline 1 & Pratindakan & 41,8 & 12 \\
2 & Siklus I & 49,6 & 18 \\
3 & Siklus II & 86,16 & 84 \\
\hline
\end{tabular}

Berdasarkan tabel 3 maka dapat diketahui skor pratidakan 41,8 dengan persentase 12 . Pada siklus I terdapat skor 49,6 dengan persentase 18. Pada siklus II terdapat skor 86,16 dengan persentase 84. Pada pratindakan ke siklus I terdapat kenaikan skor 7,8 dengan kenaikan persentase 6 persen. Pada siklus I ke siklus II terdapat kenaikan skor 36, 56 dengan kenaikan persentase 66 persen. Berdasarkan hasil siklus II penelitian ini di hentikan karena sudah memenuhi kritreia ketercapaian.

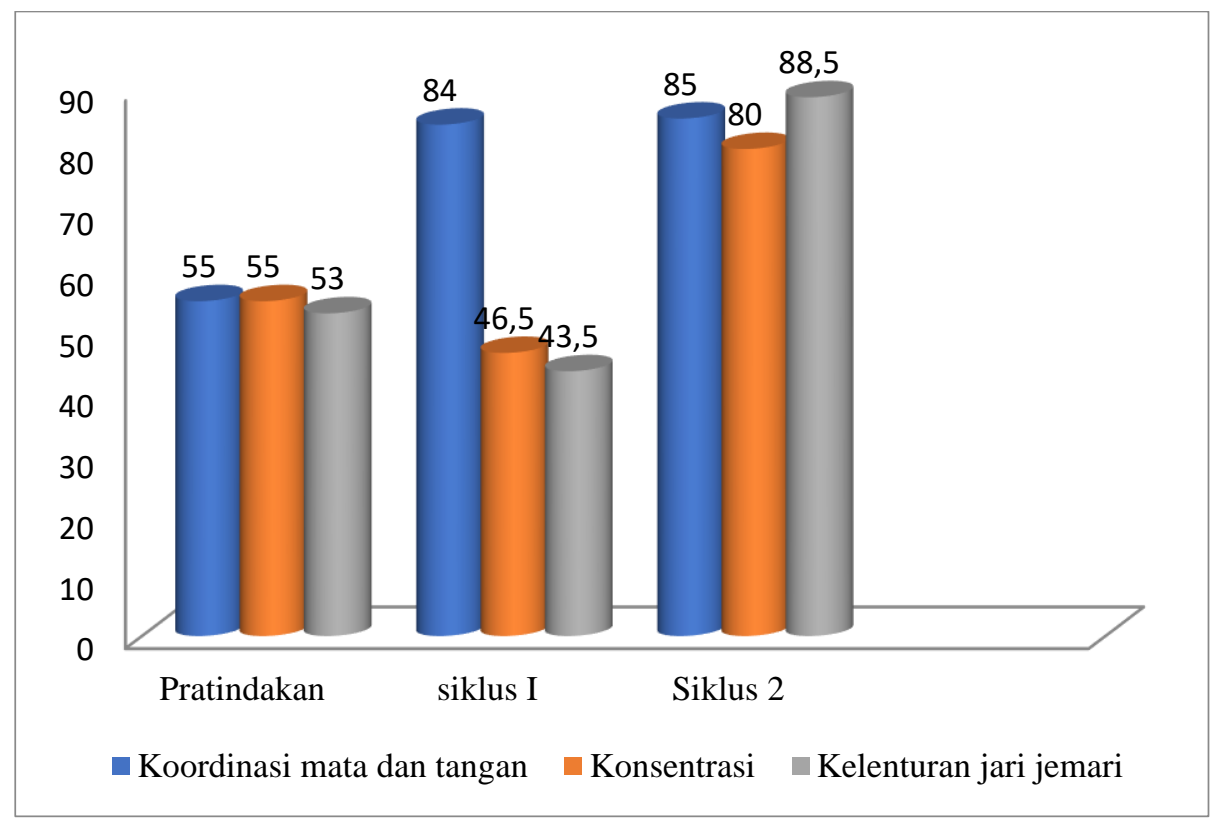

Gambar 2. Hasil peningkatan kemampuan motorik halus anak melalui kegiatan menganyam menggunakan eceng gondok dengan teknik kepang dari pratindakan siklus I dan siklus II.

Pada gambar 2 dapat dilihat bahwa kemampuan motorik halus anak pada penelitian pratindakan koordinasi mata dan tangan dengan nilai 55, konsentrasi 55 dan kelenturan jari jemari 53. Pada siklus I nilai keseluruan koordinasi mata dan tangan 84, konsentrasi 46,6 dan kelenturan jari jemari tangan 43,5 dengan kategori mulai berkembang oleh karena itu peneliti dilanjut dengan siklus selanjutnya. Pada siklus II koordinasi mata dan tangan dengan nilai 85, konsentrasi 80 dan jari jemari tangan 88,5 dengan kategori berkembang sangat baik. Hasil dari analisis data pada penelitian siklus I dapat dilihat bahwa ketercapaian kelas pada siklus I belum memenuhi standar ketercapaian yang peneliti harapkan untuk meningkatkan peneliti dilanjut dengan siklus berikutnya. kemampuan motorik halus anak melalui kegiatan menganyam menggunakan eceng gondok dengan teknik kepang. Pada siklus II telah ditemukan bahwa kemampuan motorik halus anak memalalui kegiatan menganyam menggunakan menggunakan eceng gondok meningkat melebihi standar ketercapaian yang peneliti harapkan yaitu 70\% peningkatan tersebut dikarenakan (1) anak-anak benar-benar konsentrasi langkah- 
langkah yang dijelaskan oleh guru untuk melakukan kegiatan menganyam menggunakan eceng gondok dengan teknik kepang pada setiap langkahnya (2) anak benar-benr memperhatikan sehingga ketercapaian anak meningkat (3) setelah adanya perbaikan pada siklus II membantu anak untuk mencapai ketercapaian dalam mengembangkan motorik halusnya, terutama dalam aspek koordinasi, konsentrasi dan kelenturan dalam melakukan kegiatan menganyam menggunakan eceng gondok dengan teknik kepang. Melalui hasil persentase siklus II tersebut, ketercapaian belajar anak di TK Mekarsari Lamongan pada pembelajaran motorik halus melalui kegiatan menganyam menggunakan eceng gondok dengan teknik kepang mendapatkan ketogori berkembang sangat baik.

Pada masa anak usia dini penyerapan informasi yang akan berlangsung sangat cepat dan tepat dalam merespon informasi, sehingga pada masa ini anak akan banyak melakukan peniruan terhadap bahasa, emosional, dan perilaku yang melibatkan gerakan-gerakan pada tubuh anak. Masa ini dikenal dengan masa the golden age (Aisyah, 2013:14). Kegiatan menganyam menyesuaikan pada pembelajaran di TK Mekarsari Lamongan. Aspek yang dinilai dalam melakukan kegiatan menganyam ini berhubungan dengan peningkatan motorik halus anak dalam koordinasi antara mata dan tangan, konsentrasi anak, dan kelenturan jari jemari tangan anak.

Fisik motorik di bagi menjadi 2 motorik kasar dan motorik halus. Motorik kasar yaitu koordinasi kelompok otot-otot anak yang tertentu dapat membuat anak melompat, memanjat, berlari dan menaiki sepeda, sedangkan motorik halus yaitu meningkatnya pengordinasian gerak tubuh yang melibatkan otot syaraf yang jauh lebih kecil atau detail. Kelompok otot dan syaraf inilah yang nantinya mampu mengembangkan gerak motorik halus, seperti meremas kertas, menyobek, menggambar, dan menulis (Suyadi, 2010:69). Sejalan dengan Sumantri (2005:143) perkembangan motorik halus merupakan pengorganisasian penggunaan sekolompok otot-otot kecil seperti jari-jemari dan tangan yang sering membutuhkan kecermatan dan koordinasi mata dengan tangan. Pengendalian yang baik yang memungkinkannya melakukan ketepatan dan kecermatan dalam gerak. Berhubungan dengan kemampuan anak untuk melakukan gerakan pada bagian-bagian tubuh tertentu saja dapat dilakukan oleh otot-otot kecil tetapi memerlukan koordinasi yang cermat.

Penerapan kegiatan menganyam dapat melatih anak untuk kelenturan jari-jemarinya ketika memasukkan eceng gondok kedalam pola yang sudah ditentukan. Pada penelitian ini telah membuktikan bahwa melalui kegiatan menganyam menggunakan eceng gondok dengan teknik kepang dapat meningkatkan kemampuan peningkatan motorik halus anak. Pelaksanaan siklus I anak-anak terlihat sangat kesulitan dalam memasukkan eceng gondok ke dalam pola anyaman yang sudah ditentukan. Anak-anak masih sulit dikondisikan dan ramai sendiri, pada pertemuan kedua anak-anak mulai bisa memasukkan eceng gondok kedalam pola anyaman.

keterampilan dasar menganyam menurut pendapat Nasir (2013:50) adalah menyatakan bahwa salah satu bagian dari kemampuan yang bertujuan dapat menghasilkan benda seni yang dilakukan dengan cara saling menyusupkan atau menumpang tindihkan bagian anyaman secara bergantian hingga menyatu. Keterampilan dasar menganyam untuk anak usia dini tidak harus dilakukan dengan pendekatan yang spesifik, tetapi masih dalam tahap pendekatan dasar menganyam sederhana.

Kegiatan menganyam mengguakan eceng adalah kegiatan yang telah peneliti pilih sebagai upaya salah satu dalam meningkatkan keterampilan motorik halus anak. Kegiatan 
menganyam menggunakan eceng gondok ini membuat anak-anak tertarik dan antusias mendengernya. Terdapat beberapa macam jenis bahan anyaman yang dapat digunakan dalam kegiatan praktik keterampilan dasar menganyam di TK menurut Sumanto (2005:121-122) sebagai berikut salah satunya eceng gondok. Enceng gondok merupakan tanaman yang mengapung di permukaan air. Agar dapat digunakan sebagai bahan anyaman enceng gondok menggunakan tangkainya saja, setelah tangkai dibersikan menggunakan air bersih, tangkai enceng gondok dijemur sampai kering. Kegiatan menganyam menggunakan eceng gondok dengan teknik kepang dapat meningkatkan kemampuan motorik halus anak dalam melakukan gerakan menganyam membutuhkan koordinasi mata dan tangan.

\section{Simpulan}

Berdasarkan hasil penelitian dan pembahasan tentang peningkatan kemampuan motorik anak melalui kegiatan menganyam menggunakan eceng gondok dengan teknik kepang pada kelompok B TK Mekarsari Lamongan dapat disimpulkan bahwa kegiatan menganyam eceng gondok dengan teknik kepang terlaksana dengan baik sesuai dengan langkah-langkah. Kegiatan menganyam menggunakan eceng gondok dengan teknik kepang dapat meningkatkan motorik anak yang meliputi dengan aspek koordinasi antara mata dan tangan, konstrasi anak dan kelunturan jari jemari anak. Terkait dengan koordinasi mata dan tangan anak sudah mulai bisa mengkoordinasikan antara mata dan tangan anak, selanjutnya adalah konsentrasi anak sudah bisa berkonsentrasi penuh ketika melakukan kegiatan menganyam menggunakan eceng gondok dengan teknik kepang dan terakhir berkaitan tentang kelenturan jari jemari anak, anak sudah mulai lentur ketika memasukkan eceng gondok kedalam pola anyaman.

\section{Daftar Rujukan}

Aisyah, S. (2013). Perkembangan dan Konsep Dasar Pengembangan Anak Usia Dini. Jakarta: Universitas Terbuka.

Akbar, S. (2010). Penelitian Tindakan Kelas:filosofif, metodologi, implementasi. Yogyakarta: CV. Cipta Media.

Arikunto, S. (2010). Prosedur Penelitian. Jakarta: Rineka Cipta

Nasir, H. Y. (2013). Gerbang Jagat Kerajinan Tangan, Jakarta: PT Bumi Aksara.

Sumanto. (2005). Pengembangan Kreativitas Seni Rupa Anak TK. Jakarta: Depdiknas.

Sumantri. (2005). Model Pengembangan Keterampilan Motorik Anak Usia Dini. Jakarta: Depdiknas.

Suyadi. (2010). Psikologi Belajar Paud. Yogyakarta: PT Bintang Pustaka Abadi.

Trianto. (2011). Mendesain Model Pembelajaran Inovatif Progresif. Jakarta: Kencana. 